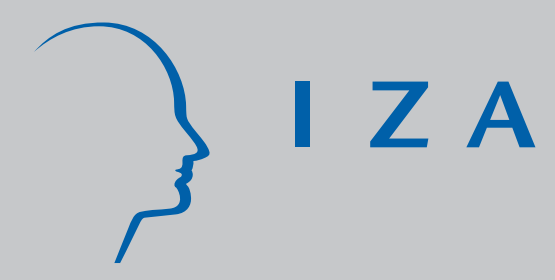

IZADP No. 2569

Political Institutions and the Development of Telecommunications

Veneta Andonova
Luis Diaz-Serrano

J anuary 2007 


\title{
Political Institutions and the Development of Telecommunications
}

\author{
Veneta Andonova \\ Universidad de los Andes \\ Luis Diaz-Serrano \\ Universitat Rovira $i$ Virgili, \\ CREB and IZA
}

\section{Discussion Paper No. 2569 \\ January 2007}

IZA
P.O. Box 7240
53072 Bonn
Germany

\author{
Phone: +49-228-3894-0 \\ Fax: +49-228-3894-180 \\ E-mail: iza@iza.org
}

\begin{abstract}
Any opinions expressed here are those of the author(s) and not those of the institute. Research disseminated by IZA may include views on policy, but the institute itself takes no institutional policy positions.
\end{abstract}

The Institute for the Study of Labor (IZA) in Bonn is a local and virtual international research center and a place of communication between science, politics and business. IZA is an independent nonprofit company supported by Deutsche Post World Net. The center is associated with the University of Bonn and offers a stimulating research environment through its research networks, research support, and visitors and doctoral programs. IZA engages in (i) original and internationally competitive research in all fields of labor economics, (ii) development of policy concepts, and (iii) dissemination of research results and concepts to the interested public.

IZA Discussion Papers often represent preliminary work and are circulated to encourage discussion. Citation of such a paper should account for its provisional character. A revised version may be available directly from the author. 
IZA Discussion Paper No. 2569

January 2007

\section{ABSTRACT}

\section{Political Institutions and the Development of Telecommunications}

It has traditionally been argued that the development of telecommunications infrastructure is dependent on the quality of countries' political institutions. We estimate the effect of political institutions on the diffusion of three telecommunications services and find it to be much smaller in cellular telephony than in the others. By evaluating the importance of institutions for technologies rather than for industries, we reveal important growth opportunities for developing countries and offer policy implications for alleviating differences between countries in international telecommunications development.

JEL Classification: $\quad 01, \mathrm{O} 3$

Keywords: political constraints, telecommunications, GMM, economic development

Corresponding author:

Luis Diaz-Serrano

Department of Economics

Universitat Rovira i Virgili

Av. de la Universitat, 1

43204 Reus

Spain

E-mail: luis.diaz70@gmail.com 


\section{Introduction}

It has traditionally been argued that the development of basic infrastructure in telecommunications is dependent on the quality of countries' institutions in general and on their political institutions in particular (Esfahani and Ramírez, 2003; Henisz and Zelner, 2001; Levy and Spiller, 1996). The reason, which applies for all utilities sectors, is that the existence of political checks and balances reduces the probability of hold-up or expropriation of the investment by the government. Infrastructure investments are believed to suffer from a number of market imperfections such as the economies of scale generated by network externalities, which increase the role of governments (North, 1990; Williamson, 1988). In principle, governments should only be interested in regulating these externalities but occasionally they may try to redistribute wealth and expropriate investors in order to obtain political credit. In the case of telecommunications, an opportunistic government might ex-post expropriate the heavy capital investment in infrastructure and guarantee at least a temporarily cheap service to its citizens, an action that would arguably result in some internal political credit. The chance of this happening can be evaluated by looking at investor surveys and indicators such as the International Country Risk Guide or structurally-derived indices of the local polity such as the POLCON index proposed by Henisz (2000). In order to avoid the risk of expropriation, investors are advised to avoid the poor institutional settings that are typical of many developing countries, even when local market conditions advise otherwise (Henisz and Zelner, 2001: 132). We argue that both investors and developing nations can do better if appropriate technologies are available.

We study the evolution of three information and communication technologies in 183 countries for the period 1990-2004 and show that telecommunications dependence on superior political institutions is greatly reduced in the case of cellular telephony. From an institutional perspective, cellular telephony has two advantages when compared to communications 
technologies that rely heavily on fixed-line infrastructure. First, cellular networks are built faster than fixed-line networks; they are cheaper and need fewer subscribers to reach a minimally efficient scale. Second, the assets on which cellular telephony relies are re-deployable and less site-specific. In essence, in the case of telecommunications, lower capital requirements and higher asset mobility arguably compensate for poor political institutions. Thus, evaluation of the importance of institutions for different technologies rather than for the industry of telecommunications as a whole may reveal important growth opportunities for developing countries.

Our results are relevant for academics, policymakers and investors alike. Interest in the study of institutions, including political institutions, has triggered an enormous amount of literature with surprisingly few practical implications beside the fact that institutions matter. In this paper, we offer some actionable knowledge when considerable improvements in political institutions are unlikely. We study the relationship between the diffusion of three telecommunications technologies and political institutions across 183 countries during the period 1990-2004. We argue that, by picking the technology that fits into their institutional environment, policymakers and investors can do one of the things within their powers to foster technological adoption and the consequent economic development. To the best of our knowledge, this is the first panel-data study that looks at the potential of different technologies, among the available alternatives, according to countries' political institutions. ${ }^{1}$ Empirically, our contribution is threefold: first, we evaluate the impact of political institutions at technology rather than at industry level; second, we include many more countries than previous studies on related issues have done (notably Henisz and Zelner, 2001); and third, by using a GMM variant of the Arellano

\footnotetext{
${ }^{1}$ Andonova (2006) empirically investigates the determinants of Internet and cellular phone penetration levels in a cross-country setting taking into account a number of institutional variables.
} 
and Bond (2001) estimator, we effectively deal with endogeneity, which is frequently poorly managed in studies using institutional variables.

This article begins with a brief overview of the role of telecommunications technologies for economic growth. Then we describe how fixed telephony, cellular telephony and Internet connectivity differ in the requirements they make on the institutional environment. We hypothesize that technologies built on cheap, re-deployable modules require fewer institutional guarantees in order to expand than more expensive technologies built on site-specific assets. Next, we present the econometric analysis of the panel showing that in the case of telecommunications, the dissemination of cellular technology is less dependent on political institutions than others. Finally, we discuss the prospects for economic growth in the light of the existing evidence and offer some policy recommendations.

\section{Telecommunications and development}

It has long been argued that telecommunications spur development and growth (Garbade and Silber, 1978; DuBoff, 1980; Hardy, 1980; Nathaniel, 1984; Norton, 1992). As a mechanism for reducing information asymmetry, telecommunications are expected to facilitate economically beneficial transactions, positively affecting a series of indicators, among them productivity and economic growth. Empirically, these relations had been hard to demonstrate and for many years economists considered there was a "productivity paradox" in their failed attempts to find a positive relationship between investments in information technology and productivity (Berndt and Morrison, 1995). Eventually a complex relationship characterized by time lags and nonlinearities was confirmed (Bassu, Fernald, Oulton and Srinivasan, 2003; Brynjolfsson and Hitt, 1996, 2000; Dunne, Foster, Haltiwanger and Troske, 1999). On firm level, telecommunications are believed to allow for more flexible and geographically disperse organizations that benefit 
from regional comparative advantages (Wellenius, 1977; Yilmaz, Haynes and Dinc, 2002). Thus, telecommunications investment has been treated as a growing source of productivity gains for firms that have to deal with the increasingly information-intensive nature of production (Warf, 1995) and those that actively use outsourcing and multiple locations. At the same time, investment in telecommunications infrastructure is found to exhibit negative spillover effects, becoming a competitive tool for attracting factors of production (Yilmaz et al., 2002).

In addition, many of the studies that establish a relationship between infrastructure, including telecommunications, and economic growth (Aschauer, 1989a,b; Easterly and Rebelo, 1993; Canning, Fay, Perotti, 1994; Sanchez-Robles, 1998) have become controversial, mainly because of unaddressed endogeneity and the direction of causality. After taking into account these criticisms, Esfahani and Ramírez (2002) perform a careful estimation of the effects between infrastructure, including telecommunications, and GDP and report that the impact of infrastructure on GDP growth "turns out to be substantial" (p. 470). The effect of telecommunications on indicators like productivity and economic growth seems, eventually, to have been carefully proven. However, the economic relevance of this result has recently been questioned by Roller and Waverman (2001) who, by simultaneously estimating a micro model for telecommunications investment with a macro production function for the OECD countries, find a strong causal relationship between telecommunications infrastructure and productivity only when telecommunications services reach near universal levels.

In general, telecommunications are shown to have a positive effect on different measures of economic development and productivity; however, there is some degree of controversy related to the empirical robustness, sample size and economic relevance of the effects reported by different studies. Assuming that such a positive relation is generally proven, our goal here is to 
study to what extent the degree of political risks affects the diffusion of three different telecommunications technologies.

\section{Institutions and the diffusion of three communications technologies}

It is argued that telecommunications, together with other utilities such as electricity, depend greatly on local political institutions because the technology relies on large sunk investments in specific assets, is characterized by economies of scale and scope, and the output is massively demanded by the general public (Bergara, Henisz and Spiller, 1998). The received wisdom is that such characteristics make the contracting process in these industries very politicized and, therefore, dependent on the countries' political institutions. In the case of telecommunications, the above-mentioned traits are commonly conceived as characteristics of the sector rather than of a specific technology. In the past, such an assumption might have been valid for the purpose of simplification. Since the massive penetration of cellular telephony and Internet connectivity, however, industry- rather than technology-centered studies severely limit our understanding of the role of political institutions for the development of telecommunications worldwide.

Today, within the telecommunications industry, there are at least three massively-used means of communication: fixed telephony, cellular telephony and Internet. There are important technological differences between them related to the size of the investment involved and the specificity of the assets on which each of the three relies. For example, cellular networks can be installed more rapidly and cheaply than fixed (ITU, 1999, p. 5). Installation is fast because there is no need for new wired lines and networks use installed fixed lines for links between cell sites. “Technically, there are no lines to lay to the subscriber's premises; put in a few base stations and a switch and service is available for anyone with a handset” (ITU, 1999; pp. 62). Also, if built 
today, mobile networks are much cheaper to deploy than fixed networks (ITU, 1999; pp. 61; 83). In fact, fixed networks have stopped growing and are actually declining in many countries, if Integrated Services Digital Network (ISDN) lines are not taken into account. ISDN lines add between two and thirty "virtual" connections to an existing fixed line. The reason for the increase in ISDN is the growing demand for Internet access that is still dependent on the fixed-line network (ITU, 1999: p. 2-3).

Differences in the value and site-specificity of the assets on which different telecommunication technologies rely may pose different requirements on the degree of political commitment that is demanded for each of them. We expect the communication technologies that rely heavily on site-specific assets and require larger up-front investments such as the deployment of basic infrastructure ${ }^{2}$ and the provision of Internet connectivity to show higher dependence on political institutions than cellular telephony, which is built on mobile and re-deployable modules. This is because technologies relying on expensive site-specific assets are more exposed to possible governmental hold-up, so the diffusion of such technologies would depend more on the political predictability of host countries. In fact, we predict that countries whose institutional development does not provide sufficient political guarantees for investment in Internet connectivity might still be sufficiently attractive for investment in cellular telephony, given the mobility and lower cost of its assets.

\section{The dataset and variables}

\footnotetext{
${ }^{2}$ As we emphasize below, the effect of the political institutions on the diffusion of basic infrastructure approximated by the number of main lines in operation cannot be fully appreciated given the time span of our study, 1990-2004. During this period, fixed-line telephony stopped growing in many countries as they achieved near universal adoption while others were close to universal usage. Most previous studies of the effect of political institutions on the telecommunications sector focus exclusively on the variable for main lines in operations and find a strong and statistically significant coefficient (see, for example, Henisz and Zelner (2001), who use the same proxy for political commitment).
} 
We study the impact that national political institutions for investment protection have on the penetration rate of three different communications technologies: fixed-line telephony, Internet and cellular telephony. These three technologies rely on assets with different degrees of value and specificity so, if the hold-up hypothesis for infrastructure investment is correct, they would require a different degree of political commitment for investor protection.

We use economic and demographic data from the World Bank’s World Development Indicators (2005) and the International Telecommunication Union (2005) databases. The proxy for political commitment measured by the level of constraints on executive discretion is taken from the POLCON 2005 database. $^{3}$ Our dataset contains information for 214 countries over the period 1980-2004. However, a number of countries do not report data for the decade 1980-1990 on many of the variables we use. Therefore, we restrict the sample to the period 1990-2004 and to 183 countries. The reduction in the sample size is traded against the quality of the data and the robustness of the estimates.

We use three dependent variables: Main Lines (ML), Internet Hosts (IH) and Cellular Phone Subscribers (SPS) are proxies for the development of fixed telephony, Internet connectivity and cellular telephony, respectively. Main Lines $(M L)$ are the per capita main telephone lines in operation connecting the subscriber's terminal equipment to a public, switched network having a dedicated part in the telephone exchange equipment (ITU, 2005). Internet Hosts $(\mathrm{IH})$ are the per capita number of computers in an economy that are directly linked to the worldwide Internet network. We choose to use Internet Hosts instead of Internet Users as a proxy for Internet penetration for reasons of quality. Internet Users are the per capita estimated number

\footnotetext{
${ }^{3}$ The POLCON variable was initially proposed by Henisz (2000) and it has been periodically updated since then. We chose this variable because it is an objective and conservative measure among the available indices of political risks. First, it is a more objective measure of government commitment than, for example, the "contract repudiation" indicator available for the International Country Risk Guide (ICRG). Second, the two variables are reported to be
} 
of Internet users based on the reports of Internet Access Provider subscriber counts or calculated by multiplying the number of Internet hosts by an estimated multiplier. This methodology may considerably understate the number of Internet users in developing countries (Chinn and Fairlie, 2004). Cellular Phone Subscribers (CPS) are the per capita cellular telephone subscribers. This may include subscribers to analog and digital cellular systems.

We choose to use POLCON as a proxy for the political commitment for investor protection. POLCON is a structurally derived and internationally comparable index that reflects the degree to which the national political institutions, together with the preferences of political actors, constrain effects on government policy (Henisz and Zelner, 2001). In essence, using political science databases, the POLCON index represents a measure of institutional hazards, taking into account the number of veto points on a policy change and the homogeneity of preferences of political players. This variable ranges from 0 to 1 and is calculated on a yearly basis. It can be interpreted as an objective measure of the degree to which investors' interests are protected by a given polity and it has one important advantage to the subjective risk ratings based on managerial surveys like International Country Risk Guide indicators. Subjective ratings are only indirectly related to the structure of political institutions while POLCON is a direct measure of it. In Table 1 we show the mean average value of the POLCON variable during the sample period, i.e. $1990-2004$.

\section{Insert Table 1 about here}

We also take into account a number of demand and supply side controls for infrastructure: waiting lists for main lines (WL), annual per capita investment in telecommunications (TI), GDP 
per capita (GDP), number of Internet users (IU) and the peak rate of mobile (Price CPS) and fixed-phone (Price ML) 3-minute local calls. In Table 2 we show summary statistics on the variables used in the analysis.

Insert Table 2 about here

\section{The econometric model}

To empirically test the above-hypothesized relationships, we estimate several reducedform equations for technology adoption rates. The core specification of our model is similar to that in Henisz and Zelner (2001). To explain technology adoption, we determine the following linear relationship:

$$
\Delta y_{i, t}=\alpha+\beta y_{i, t-1}+\delta X_{i, t}+\varepsilon_{i, t}
$$

where the endogenous variable $y_{i, t}$ can be the logarithm of main lines $(\mathrm{ML})$, Internet hosts (IH) or cellular phone subscribers (CPS) for country $i$ at period $t$; $\Delta$ is the difference operator (since the variables are in logarithms, it is equivalent to the growth rate); $X_{i t}$ is a matrix containing a set of covariates, $\varepsilon_{i t}$ is a normally distributed random error term, and $\alpha, \beta$ and $\delta$ are a set of parameters to be estimated. Given that there is substantial heterogeneity, generally unobserved, among countries in their telecommunication technology penetration rates, if we decompose the random error term $\varepsilon_{i t}$, model (1) can be expressed as 


$$
\Delta y_{i, t}=\alpha+\beta y_{i, t-1}+\delta X_{i, t}+u_{i}+\gamma_{t}+e_{i, t}
$$

where $u_{i}$ is a time-constant specific country effect; $\gamma_{t}$ is a time-specific effect, and $e_{i t}$ is a timevarying error term, with $\rho=\frac{\sigma_{u}^{2}}{\sigma_{e}^{2}+\sigma_{u}^{2}}$. In our study, the estimation of $\rho$ becomes relevant, since it measures the relative importance of the country-specific, unobserved effects on the adoption of technology. If we assume that $E\left[u_{i}, \beta y_{t-1}+\delta X_{i t}\right] \neq 0$, one candidate for estimating model (2) is the linear regression panel data model with fixed effects. The time-specific effect $\gamma_{t}$ can be easily captured by including time dummies. Alternatively, a pooled OLS estimate of equation (1) that includes time and country dummies would provide the same results as those obtained by the panel data fixed-effects model. However, this estimation method will provide inconsistent estimates of the parameters involved in equation (2). To overcome this problem, we use a variant of the Arellano and Bond (1991) GMM estimator.

The estimation method used here can be described as follows. Consider the following general linear relationship with country fixed effects:

$$
y_{i, t}=\beta y_{i, t-1}+\delta X_{i, t}+u_{i}+e_{i, t}
$$

The strategy used to estimate equation (3) consists in differencing the equation in order to remove the country-specific effect $u_{i}$

$$
y_{i, t}-y_{i, t-1}=\beta\left(y_{i, t-1}-y_{i, t-2}\right)+\delta\left(X_{i, t}-X_{i, t-1}\right)+\left(e_{i, t}-e_{i, t-1}\right)
$$


However, differencing means that even strictly exogenous variables become endogenous, in addition to the presence of non-strictly exogenous variables. Therefore, by construction, in equation (4) we have the lagged difference of our endogenous variable and it may be that the difference of other explanatory variables is correlated with the error term, which in turn creates a severe problem of endogeneity. Hence, our core specification will include not only correlated and heteroskedastic residuals, but also non-strictly exogenous and endogenous variables as covariates. In this context, a fixed-effects model with the Newey-West corrected covariance matrix provides consistent estimates of the standard errors in the presence of serial correlation and heteroskedasticity in the residuals. However, the presence of endogenous covariates creates severe identification problems in the econometric estimation that in turn lead to inconsistent estimate of model (2).

To deal with this problem of endogeneity, we use a variant of the estimation method based on the generalized method of moments (GMM) proposed in Arellano and Bond (1991). The GMM estimator proposed by these authors treats the equation to be estimated as a system of equations, one for each period. Hence, the first differences of the endogenous and non-strictly exogenous variables are instrumented with lags for the same variables in levels, but imposing the following moment conditions:

$$
\begin{aligned}
& E\left[y_{i, t-k}\left(e_{i, t}-e_{i, t-1}\right)\right]=0 ; \quad k \geq 2 ; \quad t \geq 3 \\
& E\left[X_{i, t-k}\left(e_{i, t}-e_{i, t-1}\right)\right]=0 ; \quad k \geq 2 ; \quad t \geq 3
\end{aligned}
$$

However, Arellano and Bover (1995), Blundell and Bond (1998) and Bond (2002) show that often lags for the levels of these variables are poor instruments, and they suggest suitable 
conditions for fixing this problem. One alternative is to instrument endogenous and non-strictly exogenous variables with lags of their own first differences, instead of with lags for the variables in levels. The GMM variant of the original Arellano and Bond's estimator used here incorporates these elements. In particular, the method we use here has both one- and two-step versions. We have decided to adopt the more efficient two-step method although it tends to be downward biased. In other to fix this, we apply the finite-sample correction of the two-step covariance matrix proposed in Windmeijer (2005). ${ }^{4}$

In our core model, the matrix $X_{i t}$ contains the following variables, i.e. lagged POLCON, the lagged logarithm for GDP, the GDP growth rate between period $t$ and $t-1$, the lagged logarithm for user prices (PRICE), the investment in telecommunications technology (TI) as a percentage of the lagged GDP, and the multiplicative interaction between the first lag for POLCON and the first lag for the respective technology variable, i.e. main lines (ML), Internet hosts (IH), or cellular phone subscribers (CPS). According to this core specification, equation (2) can be expressed as

$$
\begin{gathered}
\log \left(\frac{C T_{i, t}}{C T_{i, t-1}}\right)=\alpha+\beta \log M L_{i, t-1}+\delta_{1} \log G D P_{i, t-1}+\delta_{2} \log \left(\frac{G D P_{i, t}}{G D P_{i, t-1}}\right)+\delta_{3} \log P_{R I C E_{t-1}} \\
\quad+\delta_{4}\left(\frac{T I_{i, t-1}}{G D P_{i, t-1}}\right)+\delta_{5} P O L C O N_{i, t-1}+\delta_{6}\left(P O L C O N_{i, t-1} \cdot \log C T_{i, t-1}\right)+u_{i}+\gamma_{t}+e_{i, t}
\end{gathered}
$$

where the CT is the corresponding communication technology, which is replaced by ML, IH or CPS. When estimating the core model expressed in equation (3) for Mail Lines and Internet

\footnotetext{
${ }^{4}$ See Roodman (2005) for details.
} 
Hosts, we also allow for additional demand controls such as the logarithm of the per capita number of people on waiting lists for main lines (WL) and the logarithm of the per capita number of Internet users (IU), respectively.

\section{Empirical results}

In Table 3 we report the results from estimating our core model as specified in equation (3) by both the Generalized Method of Moments (column labeled as GMM) and the linear paneldata model with fixed effects (column labeled as FE) for our three endogenous variables: Main Lines (ML), Cellular Phone Subscribers (CPS) and Internet Hosts (IH). Recall that our core model specifies the technology penetration level as a function of the first lag of the same technology penetration level, the real gross domestic product lagged one period and in first differences, POLCON lagged one period, and the multiplicative interaction between the first lag of the penetration level and POLCON.

Insert Table 3 about here

Although we provide the results coming from both estimation methods, i.e. fixed-effects and GMM, we will focus on the GMM estimates only because of the advantages of this estimation procedure. ${ }^{5}$ We start by discussing the effects of the proxy for political institutions (POLCON) on the technology variables. As expected, POLCON has turned out to be statistically significant and positive. This result is consistent with that observed in earlier studies and indicates that political institutions are important for the diffusion of all telecommunications technologies. In addition, we find that the effect of the POLCON variable is smaller for CPS than for $\mathrm{ML}$ and $\mathrm{IH}$. We consider this result to be quite important, since it confirms the main

\footnotetext{
${ }^{5}$ In model (3), $\hat{\beta}, \hat{\delta}_{1}, \hat{\delta}_{2}, \hat{\delta}_{3}$ and $\hat{\delta}_{4}$ are elasticities, while $\hat{\delta}_{5}$ and $\hat{\delta}_{6}$ are semi-elasticities.
} 
hypothesis we propose in this study, namely that the diffusion of cellular technology requires a relatively lower degree of political predictability and institutionally-supported investor protection. The semi-elasticities for the variable POLCON presented in Table 3 show that an increase of 0.1 in the political constraints score increases the penetration rate of cellular telephony (CPS) by around 2 percent. The effects for the penetration level of main lines (ML) and Internet hosts (IH) are 3.4 and 17 percent, respectively. The relevant comparison is between the coefficients of POLCON for cellular telephony ( 2 percent) and Internet hosts (20 percent), given that fixed telephony (3.4 percent) is very advanced in its life cycle for the time period under study. Once we add the first lag of the logarithm of the per capita number of people on waiting lists for main lines to the core model, the level of POLCON coefficient for ML remains the same. However, in the case of the penetration level of Internet hosts (IH), this rises by up to 28 percent once we include a control for the per capita number of Internet users (IU).

The interaction variable $\left(y_{t-1} P O L C O N_{t-1}\right)$ is also statistically significant and negative for main lines (ML) and cellular phone subscribers (CPS), implying a positive but decreasing effect of political institutions on the diffusion of these technologies. This result suggests that the presence of stronger political constraints, i.e. when POLCON tends to 1, may improve the ability of laggard countries to increase their telecommunication technologies' penetration levels, creating a convergence effect. This result is expected for main lines. In our sample, we observe that fixed-line telephony penetration was quite stable during the period 1990-2004 as many countries achieved, or were close to, universal usage, resulting in weak net increases in main line diffusion, with decreases for the most advanced countries. The diffusion of cellular telephony, as with fixed telephony, is characterized by a positive and decreasing effect of political institutions but for a different reason as in our sample this technology is far from reaching universal usage. This effect is consistent with plenty of anecdotal evidence showing that cellular telephony is a 
functional substitute for fixed telephony in developing countries where basic telecommunications infrastructure is precarious and political risks are high (Davis and Ochieng, 2006). However, the interaction variable turns out to be positive for Internet hosts $(\mathrm{IH})$, indicating that the effect of political institutions on Internet connectivity for the period under study is increasing. This implies a divergence in international Internet diffusion as measured by the Internet Hosts proxy. Once again we have evidence for the differential effect of political institutions on the diffusion of telecommunications technologies.

The first lag of the dependent variable in levels $\left(y_{i, t-1}\right)$ turns out to be statistically significant and negative, which means that laggard countries experience, ceteris paribus, higher growth rates with respect to their existing level of ICT penetration. This effect is substantially larger for the growth rate of penetration of IH and CPS, since a one percent increase in the level of IH and CPS reduces the growth rate of penetration by around 0.5 and 0.4 percent, respectively. For ML this reduction is around 0.11 . This shows that there is a negative relationship between past rates of technological adoption and penetration growth rates, providing some evidence for catch-up or convergence in technological penetration. Naturally, the size of the catch-up effect is smaller for Main Lines (ML) given how advanced in its life cycle this technology is for most countries during the period of analysis, 1990-2004.

Our core specifications also include the logarithm of the level of the per capita GDP lagged one period and its first difference. On the one hand, the GDP level catches up the effect of demand. As we observe, the expected effect for this variable is statistically significant and positive which in turn indicates, in line with growth theory, that the long-run level of ICT penetration increases with the level of demand. This effect is fairly modest for the ML variable. A one percent increase in the GDP level causes growth in the ML penetration rate the next period of about 0.1 percent. These increments are markedly larger for IH and CPS, around 0.6 and 0.4 
percent, respectively. On the other hand, the first difference in GDP catches up the speed at which the increase in demand conditions growth in technology penetration. In other words, if the gap in the logarithm for GDP between $t$ and $t t_{1}$ is large enough, the GDP level appears not to be a good proxy for the demand level. This variable has reported the largest effect for the penetration rate of IH. The fact is that both variables, the GDP level and the GDP difference, have reported large effects for the IH variable.

In the extended specification of our core model, in the main lines (ML) equation we include the first lag of the logarithm of the per capita number of people on waiting lists for main lines $\log (\mathrm{WL})_{\mathrm{t}-1}$ and its first difference $\Delta \log (\mathrm{WL})_{\mathrm{t}}$. Similarly, in the IH equation, we include the first lag of the logarithm for the per capita number of Internet users $\log (\mathrm{IU})_{\mathrm{t}-1}$ and its first difference $\Delta \log (\mathrm{IU})_{\mathrm{t}}$. We find that the respective demand variable exerts a very strong effect on the penetration rate of $\mathrm{IH}$, while the effect on the $\mathrm{ML}$ variable is quite weak. This result, jointly with the effects of GDP on penetration rates, shows that demand for Internet connectivity (measured by Internet Hosts) is very much dependent on the economic possibility of acquiring a personal computer and becoming an Internet user. Finally, the effect of the first lag of the logarithm of user costs for ML and CPS, and the effect of the first lag of the technology investment as a percentage of GDP turn out to be statistically significant and with the expected signs.

In Table 3 we also report the Sargan ${ }^{6}$ test of over-identifying restrictions, which is a test of the validity of instrumental variables. ${ }^{7}$ We find that the validity of the instruments is confirmed for all the specifications used. Alternatively, we also show the results of the Arellano-Bond test

\footnotetext{
${ }^{6}$ In our results the original statistic of the Sargan test is replaced by the Hansen $\mathrm{J}$ statistic, which is robust to heteroskedasticity or autocorrelation. See Roodman (2005) for details.

${ }^{7}$ Under the null hypothesis the statistic follows a chi-square where the degrees of freedom are determined by the number of instruments used in the estimation.
} 
for autocorrelation, i.e. $A R(1)$ and $A R(2)$. We observe that $A R(1)$ structure cannot be rejected in any of the estimated models, while the AR(2) structure is rejected for all of them. ${ }^{8}$ The results of these tests indicate that there is no serial correlation between the first-differenced variables used as instruments and the first differences of the residuals $e_{i t}$. Hence they are good instruments. ${ }^{9}$

\section{Policy implications and discussion}

In this large-scale panel-data study we estimate the effect of political constraints on the diffusion of three telecommunications services, showing that institutions have differential effects on three technologies in this industry. In essence, for telecommunications over the last fourteen years we find that political institutions are important but not as much as was previously believed. The reason is that cellular or, to use a more general term, mobile technologies show lower dependence on political constraints stemming from their limited exposure to political hold-up. No previous studies of which we are aware have shown the time-persistent ability of technological alternatives to lessen the hold-up problem and, consequently, the importance of political institutions for infrastructure investment. ${ }^{10}$ Our empirical strategy and in particular the way we deal with endogeneity make our results a lot more accurate than those of most country-level studies that deal with institutional proxies.

The success of cellular telephony in countries with low political constraints (high political risks) shows that technological adoption and subsequent economic growth is possible when technologies suit the developing country's institutional environment. The implication is that

\footnotetext{
${ }^{8}$ The null hypothesis is no autocorrelation.

${ }^{9} \mathrm{An}$ AR(1) structure implies that serial autocorrelation is removed after one difference, whereas a higher order structure $\operatorname{AR}(s)$, with $s \geq 2$, means that a first difference is not enough to remove autocorrelation. Given that the estimation method used here uses as instruments the first differences, the persistence of this correlation after applying a first difference would imply that they are endogenous, and hence bad instruments.

${ }^{10}$ Andonova (2006) reports some preliminary results in a set-up similar to ours, however, she recognizes that the cross-sectional nature of her study puts a serious limitation on their generizability.
} 
investors in transition and developing countries should promote cheap, mobile, modular versions of existing technologies, thus taking advantage of otherwise attractive market conditions and greatly reducing their exposure to hold-up by opportunistic host governments. Where political institutions have a limited impact, such proactive investor behavior is justified because waiting for complex institutional reforms to take place prevents both entrepreneurs from taking profitable business opportunities and developing countries from benefiting from growth prospects.

The research reported here is not free from shortcomings. First, we do not disentangle the political constraints variable to explain the way in which institutional importance may be reduced. Second, we do not deal with telecommunications service quality. Third, despite its relative success compared to similar studies on telecommunications, the model leaves a lot of variance unexplained. This is because many of the relevant variables are not available for such a large-scale estimation. Finally, we expect that similar results hold true for other industries with large potential hold-up exposure, although readily available data on technology alternatives and how they compare with regard to asset specificity make this kind of research more difficult to perform. We plan to improve in all of these directions in future research. 


\section{References}

Andonova, V. (2006). Mobile Phones, the Internet and the Institutional Environment. Telecommunications Policy, 30, 29-45.

Arellano, M. and S. Bond. (1991). Some Tests of Specification for Panel Data: Monte Carlo Evidence and an Application to Employment Equations. The Review of Economic Studies, 58(2), 277-97.

Arellano, M. and O. Bover. (1995). Another Look at the Instrumental Variable Estimation of Error-components models. Journal of Econometrics, 68, 29-51.

Aschauer, D. (1989a). Is Public expenditure Productive? Journal of Monetary Economics, 23, 177-200.

Aschauer, D. (1989b). Does Public Capital Crowd out Private Capital? Journal of Monetary Economics, 24, 171-188.

Bergara, M., Henisz, W. and P. Spiller. (1998). Political Institutions and Electric Utility Investment: a Cross-Nation Analysis. California Management Review, 40(2), 18-35.

Berndt, E. and C. Morrison. (1995). High-tech Capital Formation and Economic Performance in U.S. Manufacturing Industries: An Explanatory Analysis. Journal of Econometrics, 65(1), 943.

Blundell, R. and S. Bond. (1998). Initial Conditions and Moment Restrictions in Dynamic Panel Data Models. Journal of Econometrics, 87, 115-43.

Bond, S. (2002). Dynamic Panel Data Models: A Guide to Micro Data Methods and Practice. Working Paper 09/02. Institute for Fiscal Studies, London.

Brynjolfsson, E. and L. Hitt. (1996). Paradox Lost? Firm-level Evidence on the Returns to Information Systems Spending. Management Science, 42(4), 541-558. 
Brynjolfsson, E. and L. Hitt. (2000). Beyond Computation: Information Technology, Organizational Transformation and Business Performance. Journal of Economic Perspectives, 14(4), 23-48.

Canning, D., Fay, M. and R. Perotti. (1994). Infrastructure and Growth. In Bsaldassarri, M., Paganetto, M. and E. Phelps (Eds.), International Differences in Growth Rates.St. Martins Press, New York, 285-310.

Chinn, M., \& Fairlie, R. (2004). The determinant of the Global Digital Divide: Across-Country Analysis of Computer and Internet Penetration. Center for Global International and Regional Studies, WP 2004-3.

DuBoff, A. (1980). Business Demand and the Development of Telegraph in the United State, 1844-1860. Business History Review, 54(4), 461-477.

Dunne, T., Foster, L., Haltiwanger, L. and K. Troske. (1999). Wage and Productivity Dispersion in U.S. Manufacturing: The Role of Computer Investment. Mimeo, Center for Economic Studies, U.S. Bureau of the Census, Washington, DC.

Easterly, W. and S. Rebelo. (1993). Fiscal Policy and Economic Growth: An Empirical Investigation. Journal of Monetary Economics, 32, 417-458.

Esfahani, H. and M. Ramírez. 2003. Institutions, Infrastructure, and Economic Growth. Journal of Development Economics, 70, 443-477.

Garbade, K. and W. Silber. (1978). Technology, Communication, and the Performance of Financial Markets, 1840-1975. Journal of Finance, 33(3), 819-832.

Hardy, A. (1980). The Role of the Telephone in Economic Development. Telecommunications Policy, 4(4), 278-286.

Henisz, W. (2000). The Institutional Environment for Economic Growth. Economics and Politics, 12(1), 1-31. 
Henisz, W. and B. Zelner. (2001). The Institutional Environment for Telecommunications Investment. Journal of Economics and Management Strategy, 10(1), 123-147.

ITU (1999). World Telecommunications Development Report. Mobile Cellular.

Levy, B. and P. Spiller. (1996). Regulations, Institutions and Commitment, Cambridge University Press, Cambridge, UK.

Nathaniel, L. (1984). Externalities, Information Costs, and Social Benefit-Cost Analysis for Economic Development: An example from Telecommunications. Economic Development and Cultural Change, 32(2), 255-276.

North, D. 1990. Institutions, Institutional Change, and the Economic Performance, New York, NY: Cambridge University Press.

Norton, S. (1992). Transaction Costs, Telecommunications, and the Microeconomics of Macroeconomic Growth. Economic Development and Cultural Change, 41(1), 175-196.

Roller, L. and L. Waverman. (2001). Telecommunications Infrastructure and Economic Development: a Simultaneous Approach. The American Economic Review, 91(4), 909-923.

Roodman, D. 2005. xtabond2: Stata Module to Extend xtabond Dynamic Panel Data Estimator. Center for Global Development, Washington.

Sanchez-Robles, B. (1998). Infrastructure Investment and Growth: Some Empirical Evidence. Contemporary Economic Policy, 16, 98-108.

Warf, B. (1995). Telecommunications and the Changing Geographies of Knowledge Transmission in the Late $20^{\text {th }}$ Century. Urban Studies, 32(2), 361-378.

Wellenius, B. (1977). Telecommunication in Developing Countries. Telecommunications Policy, 1(4), 289-297.

Williamson, O. (1988). The Logic of Economic Organization. Journal of Law, Economics and Organization, 4. 
Windmeijer, F. (2005). A Finite Sample Correction for the Variance of Linear Efficient Twostep GMM Estimators. Journal of Econometrics, 126, 25-51.

Yilmaz, S., Haynes, K. and M. Dinc. (2002). Geographic and Network Neighbors: Spillover Effects of Telecommunications Infrastructure. Journal of Regional Science, 42(2), 339-360. 
Table 1: Average values of POLCON for 183 countries for 1990-2004

\begin{tabular}{|c|c|c|c|c|c|c|c|}
\hline Country & Mean & Country & Mean & Country & Mean & Country & Mean \\
\hline Afghanistan & 0.00 & Djibouti & 0.00 & Liberia & 0.00 & San Marino & 0.19 \\
\hline Albania & 0.29 & Dominica & 0.41 & Libya & 0.00 & Sao Tome \& P. & 0.00 \\
\hline Algeria & 0.20 & Dominican Rep. & 0.40 & Liechtenstein & 0.36 & Saudi Arabia & 0.00 \\
\hline Andorra & 0.34 & Ecuador & 0.25 & Lithuania & 0.45 & Senegal & 0.22 \\
\hline Angola & 0.27 & Egypt & 0.25 & Luxembourg & 0.52 & Seychelles & 0.00 \\
\hline Antigua \& Barbuda & 0.27 & El Salvador & 0.38 & Madagascar & 0.41 & Sierra Leone & 0.05 \\
\hline Argentina & 0.46 & Equatorial Guinea & 0.01 & Malawi & 0.28 & Singapore & 0.03 \\
\hline Armenia & 0.20 & Eritrea & 0.00 & Malaysia & 0.53 & Slovak Republic & 0.52 \\
\hline Australia & 0.51 & Estonia & 0.50 & Maldives & 0.00 & Slovenia & 0.56 \\
\hline Austria & 0.46 & Ethiopia & 0.19 & Mali & 0.24 & Solomon Islands & 0.46 \\
\hline Azerbaijan & 0.00 & Fiji & 0.32 & Malta & 0.34 & Somalia & 0.00 \\
\hline Bahrain & 0.00 & Finland & 0.54 & Marshall Islands & 0.00 & South Africa & 0.33 \\
\hline Bangladesh & 0.37 & France & 0.41 & Mauritania & 0.14 & Spain & 0.48 \\
\hline Barbados & 0.19 & Gabon & 0.00 & Mauritius & 0.35 & Sri Lanka & 0.30 \\
\hline Belarus & 0.00 & Gambia & 0.05 & Mexico & 0.35 & St. Vincent \& G. & 0.21 \\
\hline Belgium & 0.71 & Georgia & 0.39 & Moldova & 0.29 & Sudan & 0.01 \\
\hline Belize & 0.27 & Germany & 0.46 & Mongolia & 0.19 & Suriname & 0.00 \\
\hline Benin & 0.47 & Ghana & 0.20 & Morocco & 0.42 & Swaziland & 0.00 \\
\hline Bhutan & 0.00 & Greece & 0.37 & Mozambique & 0.23 & Sweden & 0.49 \\
\hline Bolivia & 0.48 & Grenada & 0.30 & Myanmar & 0.00 & Switzerland & 0.63 \\
\hline Bosnia and Herz. & 0.00 & Guatemala & 0.29 & Namibia & 0.33 & Syria & 0.05 \\
\hline Botswana & 0.21 & Guinea-Bissau & 0.20 & Nauru & 0.00 & TFYR Macedonia & 0.47 \\
\hline Brazil & 0.67 & Guinea & 0.22 & Nepal & 0.28 & Taiwan. China & 0.26 \\
\hline Brunei Darussalam & 0.00 & Guyana & 0.31 & Netherlands & 0.47 & Tajikistan & 0.26 \\
\hline Bulgaria & 0.40 & Haiti & 0.21 & New Zealand & 0.41 & Tanzania & 0.28 \\
\hline Burkina Faso & 0.08 & Honduras & 0.34 & Nicaragua & 0.37 & Thailand & 0.51 \\
\hline Burundi & 0.00 & Hong Kong & 0.00 & Niger & 0.23 & Togo & 0.00 \\
\hline Cambodia & 0.26 & Hungary & 0.42 & Nigeria & 0.15 & Trinidad \& Tob. & 0.42 \\
\hline Cameroon & 0.00 & Iceland & 0.50 & Norway & 0.52 & Tunisia & 0.02 \\
\hline Canada & 0.46 & India & 0.47 & Oman & 0.00 & Turkey & 0.38 \\
\hline Cape Verde & 0.27 & Indonesia & 0.17 & Pakistan & 0.29 & Turkmenistan & 0.00 \\
\hline C. African Rep. & 0.33 & Iran (Islam. Rep. of) & 0.15 & Palau & 0.00 & Uganda & 0.13 \\
\hline Colombia & 0.39 & Iraq & 0.00 & Panama & 0.49 & Ukraine & 0.41 \\
\hline Comoros & 0.16 & Ireland & 0.45 & Papua N. Guinea & 0.60 & U. Arab Emirates & 0.00 \\
\hline Congo & 0.07 & Israel & 0.55 & Paraguay & 0.44 & United Kingdom & 0.36 \\
\hline Congo (Dem. Rep.) & 0.07 & Italy & 0.42 & Peru & 0.43 & United States & 0.40 \\
\hline Costa Rica & 0.36 & Jamaica & 0.33 & Philippines & 0.40 & Uruguay & 0.42 \\
\hline Cote d'Ivoire & 0.11 & Japan & 0.56 & Poland & 0.36 & Uzbekistan & 0.00 \\
\hline Croatia & 0.36 & Jordan & 0.37 & Portugal & 0.40 & Vanuatu & 0.40 \\
\hline Cuba & 0.00 & Kazakhstan & 0.00 & Qatar & 0.00 & Venezuela & 0.36 \\
\hline Cyprus & 0.40 & Kenya & 0.35 & Romania & 0.48 & Viet Nam & 0.04 \\
\hline Czech Republic & 0.49 & Korea (Rep. of) & 0.43 & Russia & 0.11 & Yemen & 0.00 \\
\hline Chad & 0.00 & Kuwait & 0.48 & Rwanda & 0.03 & Yugoslavia & 0.05 \\
\hline Chile & 0.50 & Kyrgyzstan & 0.15 & Saint Kitts \& N. & 0.40 & Zambia & 0.12 \\
\hline China & 0.00 & Lao P.D.R. & 0.01 & Saint Lucia & 0.24 & Zimbabwe & 0.19 \\
\hline Denmark & 0.52 & Latvia & 0.05 & Samoa & 0.44 & & \\
\hline
\end{tabular}


Table 2: Summary statistics

\begin{tabular}{|c|c|c|c|c|c|c|c|c|c|c|c|c|c|c|}
\hline & \multicolumn{2}{|c|}{$\underline{\log (\mathrm{ML})}$} & \multicolumn{2}{|c|}{$\underline{\log (\mathrm{IH})}$} & \multicolumn{2}{|c|}{$\underline{\log (\mathrm{CPS})}$} & \multicolumn{2}{|c|}{$\underline{\log (G D P)}$} & \multirow{2}{*}{$\begin{array}{r}\text { POLCON } \\
\text { levels }\end{array}$} & \multirow{2}{*}{$\begin{array}{l}\begin{array}{c}\text { (TI/GDP) } \\
* 100 \\
\text { levels }\end{array} \\
\end{array}$} & \multirow{2}{*}{$\begin{array}{r}\text { Log(IU) } \\
\text { levels }\end{array}$} & \multirow{2}{*}{$\begin{array}{r}\text { Log(WL) } \\
\text { levels }\end{array}$} & \multirow{2}{*}{$\begin{array}{c}\begin{array}{c}\text { Log } \\
\text { (Price CPS) }\end{array} \\
\text { levels }\end{array}$} & \multirow{2}{*}{$\begin{array}{r}\begin{array}{c}\text { Log } \\
\text { (Price } M L)\end{array} \\
\text { levels }\end{array}$} \\
\hline & $\Delta$ & levels & $\Delta$ & levels & $\Delta$ & Levels & $\Delta$ & levels & & & & & & \\
\hline Mean & 0.054 & 1.937 & 0.113 & -3.417 & 0.526 & 0.694 & -0.113 & 3.007 & 0.345 & 1.601 & -0.075 & -0.681 & -5.202 & -7.620 \\
\hline S.D. & 0.107 & 1.809 & 0.598 & 3.487 & 0.498 & 2.625 & 0.598 & 1.993 & 0.203 & 14.916 & 2.717 & 1.799 & 1.182 & 1.219 \\
\hline \multicolumn{15}{|l|}{$\underline{\text { Correlations }}$} \\
\hline \multicolumn{15}{|l|}{$\underline{\log (\mathrm{ML})}$} \\
\hline Levels & -0.120 & & & & & & & & & & & & & \\
\hline \multicolumn{15}{|l|}{$\underline{\log (\mathrm{IH})}$} \\
\hline$\Delta$ & 0.105 & 0.129 & & & & & & & & & & & & \\
\hline Levels & -0.248 & 0.740 & 0.007 & & & & & & & & & & & \\
\hline \multicolumn{15}{|l|}{$\underline{\log (\mathrm{CPS})}$} \\
\hline$\Delta$ & 0.186 & -0.066 & -0.028 & -0189 & & & & & & & & & & \\
\hline Levels & -2.242 & 0.609 & -0.214 & 0.764 & -0.169 & & & & & & & & & \\
\hline \multicolumn{15}{|l|}{$\underline{\log (G D P)}$} \\
\hline$\Delta$ & -0.018 & 0.059 & 0.024 & 0.041 & 0.045 & -0.010 & & & & & & & & \\
\hline Levels & -0.102 & 0.812 & 0.198 & 0.569 & -0.108 & 0.419 & 0.034 & & & & & & & \\
\hline POLCON & 0.026 & 0.312 & 0.119 & 0.349 & 0.090 & 0.204 & 0.021 & 0.354 & & & & & & \\
\hline$(\mathrm{TI} / \mathrm{GDP}) * 100$ & 0.111 & 0.077 & -0.019 & 0.183 & 0.062 & 0.211 & -0.111 & -0.036 & -0.020 & & & & & \\
\hline $\log (\mathrm{IU})$ & -0.279 & 0.563 & -0.278 & 0.778 & -0.168 & 0.868 & 0.021 & 0.314 & 0.169 & 0.280 & & & & \\
\hline $\log (\mathrm{WL})$ & 0.295 & 0.092 & 0.106 & -0.131 & 0.174 & -0.132 & -0.007 & -0.149 & -0.164 & 0.113 & -0.074 & & & \\
\hline Log(Price CPS) & -0.038 & 0.243 & 0.206 & 0.155 & 0.132 & -0.047 & 0.146 & 0.551 & 0.222 & -0.393 & -0.093 & -0.186 & & \\
\hline Log(Price ML) & -0.158 & 0.133 & 0.065 & 0.206 & -0.062 & 0.076 & 0.112 & 0.447 & 0.258 & 0.024 & 0.025 & -0.385 & 0.5739 & \\
\hline
\end{tabular}

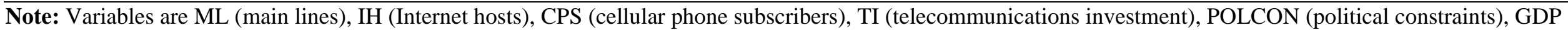

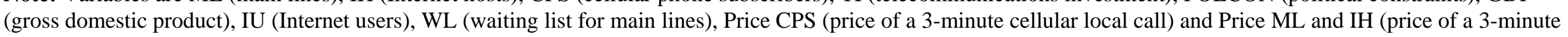
fixed-line local call) 
Table 3: Estimates of the ICT penetration level, endogenous variable is $\Delta \mathrm{y}_{\mathrm{t}}$

\begin{tabular}{|c|c|c|c|c|c|c|c|c|c|c|}
\hline & \multicolumn{2}{|c|}{$\frac{\text { Main lines (ML) }}{\text { Model } 1}$} & \multicolumn{2}{|c|}{$\begin{array}{c}\text { Cellular (CPS) } \\
\text { Model } 2\end{array}$} & \multicolumn{2}{|c|}{$\frac{\text { Internet hosts }(\mathrm{IH})}{\text { Model } 3}$} & \multicolumn{2}{|c|}{$\frac{\text { Main lines (ML) }}{\text { Model } 4}$} & \multicolumn{2}{|c|}{$\begin{array}{c}\text { Internet hosts (IH) } \\
\text { Model } 5\end{array}$} \\
\hline & $\mathrm{FE}$ & GMM & FE & GMM & FE & GMM & $\mathrm{FE}$ & GMM & $\mathrm{FE}$ & GMM \\
\hline Constant & $\begin{array}{r}0.0522 \\
(1.1)\end{array}$ & $\begin{array}{r}-0.6410 \\
(-41.9)\end{array}$ & $\begin{array}{r}0.2628 \\
(0.7)\end{array}$ & $\begin{array}{r}-1.0613 \\
(-7.2)\end{array}$ & $\begin{array}{r}-0.8891 \\
(-1.4)\end{array}$ & $\begin{array}{r}-4.2604 \\
(-27.4)\end{array}$ & $\begin{array}{r}0.0280 \\
(0.5)\end{array}$ & $\begin{array}{r}-0.7292 \\
(-36.7)\end{array}$ & $\begin{array}{r}-0.7148 \\
(-1.1)\end{array}$ & $\begin{array}{r}-4.8709 \\
(-23.3)\end{array}$ \\
\hline $\mathrm{y}_{\mathrm{t}-1}$ & $\begin{array}{r}-0.0508 \\
(-4.9)\end{array}$ & $\begin{array}{r}-0.1134 \\
(-36.1)\end{array}$ & $\begin{array}{r}-0.2191 \\
(-6.9)\end{array}$ & $\begin{array}{r}-0.3621 \\
(-18.8)\end{array}$ & $\begin{array}{r}-0.5611 \\
(-18.5)\end{array}$ & $\begin{array}{r}-0.5224 \\
(-31.3)\end{array}$ & $\begin{array}{r}-0.0997 \\
(-6.1)\end{array}$ & $\begin{array}{r}-0.1357 \\
(-44.1)\end{array}$ & $\begin{array}{r}-0.5170 \\
(-14.1)\end{array}$ & $\begin{array}{r}-0.6918 \\
(-32.4)\end{array}$ \\
\hline $\log (G D P)_{t-1}$ & $\begin{array}{r}0.0070 \\
(1.5)\end{array}$ & $\begin{array}{r}0.1050 \\
(38.2)\end{array}$ & $\begin{array}{r}-0.0797 \\
(-1.8)\end{array}$ & $\begin{array}{r}0.4031 \\
(28.5)\end{array}$ & $\begin{array}{r}-0.0269 \\
(-0.4)\end{array}$ & $\begin{array}{r}0.6698 \\
(27.9)\end{array}$ & $\begin{array}{r}0.0168 \\
(2.7)\end{array}$ & $\begin{array}{r}0.1385 \\
(35.4)\end{array}$ & $\begin{array}{r}-0.0419 \\
(-0.6)\end{array}$ & $\begin{array}{r}0.5428 \\
(20.3)\end{array}$ \\
\hline$\Delta \log (G D P)_{t}$ & $\begin{array}{r}0.0083 \\
(1.5)\end{array}$ & $\begin{array}{r}0.1717 \\
(53.2)\end{array}$ & $\begin{array}{r}-0.0121 \\
(-0.3)\end{array}$ & $\begin{array}{r}0.3011 \\
(11.2)\end{array}$ & $\begin{array}{r}0.0096 \\
(0.1)\end{array}$ & $\begin{array}{r}0.4721 \\
(15.6)\end{array}$ & $\begin{array}{r}0.0062 \\
(1.1)\end{array}$ & $\begin{array}{r}0.0709 \\
(24.4)\end{array}$ & $\begin{array}{r}-0.0067 \\
(-0.1)\end{array}$ & $\begin{array}{r}0.4889 \\
(12.6)\end{array}$ \\
\hline POLCON $_{\mathrm{t}-1}$ & $\begin{array}{r}0.0545 \\
(2.7)\end{array}$ & $\begin{array}{r}0.3424 \\
(25.7)\end{array}$ & $\begin{array}{r}-0.0253 \\
(-0.1)\end{array}$ & $\begin{array}{r}0.2017 \\
(2.6)\end{array}$ & $\begin{array}{r}-0.2384 \\
(-0.6)\end{array}$ & $\begin{array}{r}1.7303 \\
(6.4)\end{array}$ & $\begin{array}{r}0.0509 \\
(1.7)\end{array}$ & $\begin{array}{r}0.3246 \\
(20.4)\end{array}$ & $\begin{array}{r}-0.0101 \\
(0.0)\end{array}$ & $\begin{array}{r}2.8147 \\
(10.2)\end{array}$ \\
\hline $\mathrm{y}_{\mathrm{t}-1} \cdot \mathrm{POLCON}_{\mathrm{t}-1}$ & $\begin{array}{r}-0.0182 \\
(-1.8)\end{array}$ & $\begin{array}{r}-0.0694 \\
(-12.8)\end{array}$ & $\begin{array}{r}-0.1160 \\
(-1.9)\end{array}$ & $\begin{array}{r}-0.1857 \\
(-4.1)\end{array}$ & $\begin{array}{r}0.0063 \\
(0.1)\end{array}$ & $\begin{array}{r}0.0757 \\
(1.3)\end{array}$ & $\begin{array}{r}-0.0177 \\
(-1.2)\end{array}$ & $\begin{array}{r}-0.0672 \\
(-9.1)\end{array}$ & $\begin{array}{r}0.0382 \\
\quad(0.6)\end{array}$ & $\begin{array}{r}0.3774 \\
(7.3)\end{array}$ \\
\hline$(\mathrm{TI} / \mathrm{GDP})_{\mathrm{t}-1}$ & $\begin{array}{r}0.0141 \\
(4.6)\end{array}$ & $\begin{array}{r}0.0540 \\
(29.5)\end{array}$ & $\begin{array}{r}0.0242 \\
(0.7)\end{array}$ & $\begin{array}{r}0.1897 \\
(14.0)\end{array}$ & $\begin{array}{r}-0.0743 \\
(-1.8)\end{array}$ & $\begin{array}{r}0.1229 \\
(3.6)\end{array}$ & $\begin{array}{r}0.0224 \\
(5.1)\end{array}$ & $\begin{array}{r}0.0547 \\
(22.5)\end{array}$ & $\begin{array}{r}-0.0741 \\
(-1.6)\end{array}$ & $\begin{array}{r}0.1051 \\
(3.9)\end{array}$ \\
\hline Price $_{t}$ & $\begin{array}{r}-0.0087 \\
(-2.2)\end{array}$ & $\begin{array}{r}-0.0634 \\
(-39.6)\end{array}$ & $\begin{array}{r}0.0536 \\
(1.6)\end{array}$ & $\begin{array}{r}-0.1392 \\
(-8.2)\end{array}$ & $\begin{array}{r}-0.0244 \\
(-0.4)\end{array}$ & $\begin{array}{r}-0.0903 \\
(-2.2)\end{array}$ & $\begin{array}{r}-0.0094 \\
(-2.0)\end{array}$ & $\begin{array}{r}-0.0620 \\
(-42.8)\end{array}$ & $\begin{array}{r}-0.0216 \\
(-0.4)\end{array}$ & $\begin{array}{r}-0.1045 \\
(-4.4)\end{array}$ \\
\hline $\log (\mathrm{WL})_{\mathrm{t}-1}$ & & & & & & & $\begin{array}{r}0.0202 \\
(5.7)\end{array}$ & $\begin{array}{r}0.0276 \\
(25.5)\end{array}$ & & \\
\hline$\Delta \log (\mathrm{WL})_{\mathrm{t}}$ & & & & & & & $\begin{array}{r}0.0033 \\
(0.5)\end{array}$ & $\begin{array}{r}0.0062 \\
(0.6)\end{array}$ & & \\
\hline $\log (\mathrm{IU})_{\mathrm{t}-1}$ & & & & & & & & & $\begin{array}{r}-0.0548 \\
(-1.5)\end{array}$ & $\begin{array}{r}0.1677 \\
\quad(7.8) \\
\end{array}$ \\
\hline$\rho$ & 0.6535 & & 0.7485 & & 0.9009 & & 0.8589 & & 0.9009 & \\
\hline Test $\mathrm{u}_{\mathrm{i}}=0$ (F stat.) & $4.36^{*}$ & & $2.24^{*}$ & & 4.71 & & 3.55 & & 4.71 & \\
\hline Sargan test ( $\chi^{2}$ stat.) & & 113.3 & & 88.03 & & 86.98 & & 88.02 & & 91.22 \\
\hline Test AR(1) (z stat.) & & -1.77 & & -3.67 & & -4.13 & & -2.36 & & -3.52 \\
\hline Test AR(2) (z stat.) & & 1.13 & & -1.47 & & -0.39 & & -0.38 & & -0.16 \\
\hline Sample size & 1,294 & 1,234 & 697 & 616 & 828 & 907 & 855 & 806 & 862 & 818 \\
\hline
\end{tabular}

Notes: (1) All models include dummy years; $y_{t}$ is the logarithm of ML, CPS and IH per 100 inhabitants; GMM is the variant of the Arellano and Bond's estimator; FE is the linear panel data model with fixed effects estimator; standardized normal ratios in parenthesis.

(2) Variables are, TI (telecommunications investment), POLCON (political constraints), GDP (gross domestic product), IU (Internet users),

WL (waiting list for main lines), Price CPS (price of a 3-minute cellular local call) and Price ML and IH (price of a 3-minute fix-line local call) 